\title{
Atferdsvansker og oppvekstkår - En longitudinell undersøkelse av norske barnefamilier
}

\author{
Kristin S. Mathiesen \\ Regionsenter for barne- og ungdomspsykiatri, Pb. 23 Tåsen, 0801 Oslo \\ Telefon: 22028918 Telefax: 22028921 e-post: kristin.s.mathiesen@r-bup.no
}

\begin{abstract}
SAMMENDRAG
Opplysninger om problematferd, temperament, belastninger og sosiale ressurser i barnefamilier ble samlet inn fra mødre til hele årskull helsestasjonsbrukere fra 19 helsestasjoner på Østlandet (n=1081). Informasjonen ble gitt da barna var henholdsvis halvannet år og to og et halvt år. Det var $86 \%$ av de aktuelle mødrene, 932, som deltok i den førte innsamlingsrunden. Omlag $80 \%$ av dem som fylte ut det første skjemaet besvarte også spørsmålene i det neste. Resultatene støtter antakelsen om at det er mulig å identifisere problematferd allerede hos 18 måneder gamle barn. De fleste former for problematferd syntes å danne meningsfulle mønstre med distinkte kjennetegn fra dette alderstrinnet. En faktorstruktur med fire vanskedimensjoner trådte fram på begge måletidspunktene: to dimensjoner kjennetegnet av utagerende problematferd, henholdsvis vansker med "sosial tilpasning" og med "overaktivitet-passivitet"; en dimensjon knyttet til emosjonell problematferd, vansker med "emosjonell tilpasning", og en fjerde vanskedimensjon knyttet til generell umodenhet, "selvreguleringsproblemer". Disse mønstrene ligner på dem som tidligere er identifisert gjennom studier av eldre førskolebarn. Resultatene tyder også på at vi allerede fra 18 måneders alderen kan begynne å identifisere risikofaktorer i oppvekstmiljøet, og temperamentstrekk ved barna, som bidrar til å predikere hvilke barn som vil ha vedvarende utagerende eller emosjonelle problemer og hvilke som vil ha mer forbigående vansker. I tillegg til at dataene kan belyse epidemiologiske problemstillinger, har kunnskap fra studiet bidratt $\mathrm{i}$ arbeidet med å forebygge psykososiale problemer i barnefamilier.
\end{abstract}

\section{Mathiesen KS. Behaviour problems and upbringing conditions - a longitudinal study of Norwegians and their families. Nor J Epidemiol 2002; 12 (3): 199-206.}

\section{ENGLISH SUMMARY}

Information about problem behaviour, temperament, chronic strain and social resources among families with children was collected from a population-based sample of mothers when the children were 18 and 30 months of age. Of the 1081 eligible families, 932 (86\%) participated in this first part of the project. Near $80 \%$ of the mothers who filled in the first questionnaire completed the second questionnaire as well. The data suggest that it is possible to identify risk factors for stable problems at 18 months, allowing some prediction of those children whose problems will persist over early childhood. A clear factor structure involving four dimensions emerged at both assessment times: two factors were characterised by externalising behaviours, and labelled "Social adjustment" and "Overactive-inattentive"; one factor tapped internalising problems, "Emotional adjustment"; and the fourth was related to general immaturity and labelled "Regulation". The factor structure was similar to that reported by Sonuga-Barke et al. (1997). Specific patterns of child and family risk factors were associated with stability and change over the two time points for each factor. Children with stable problems had the most problematic characteristics on all significant predictors, followed by children with problems at one, but not both, time points. Since specific risk factors emerged for specific types of behaviour problems, the results may provide some guidance to early intervention efforts.

\section{INNLEDNING}

\section{Forekomst, varighet og uttrykksmåte}

En regner med at mellom 10 og 20 prosent av alle barn mellom fire og ti år har så vidt store plager at dette går ut over deres daglige fungering (Sonuga-Barke et al., 1997). Omlag en tredjepart av disse, fire til syv prosent av barnebefolkningen, antas å være klart behandlings- trengende (Prior, 1992). Noen barn har plager som kun varer $i$ en begrenset periode, mens vanskene synes å få et mer kronisk forløp hos andre. Resultater fra de få større, longitudinelle, barneprosjektene tyder på at alvorlige vansker har en urovekkende høy stabilitet (Verhulst \& Van der Ende, 1995; Prior et al., 1992). Forskningsresultater tyder på at om lag halvparten av de barna som har omfattende plager som fireåringer 
(fire til syv prosent av barnebefolkningen) også vil ha alvorlige vansker som tiåringer (Richman et al., 1982; Campbell, 1995).

Psykiske vansker uttrykkes gjennom forskjellige former for problematferd på ulike alderstrinn. Desto yngre barna er, desto vanskeligere er det å skille problematferd som antas å være forankret inne i barnet fra atferdsformer som heller bør tilskrives barnets nåtidige samspill med miljøet. Begrepet 'tilpasningsvansker' brukes derfor ofte som en fellesbetegnelse på en opphoping av problematferd hos barn som er yngre enn totre år. Hos eldre barn får gjerne en opphoping av tilsvarende atferdsformer betegnelser som atferdsvansker eller psykiske problemer.

I de tidligste aldersgruppene regner en med at problematferden er knyttet til vansker med å tilpasse seg familiens krav til rutinemessige aktiviteter - søvn, spising, renslighet og lek - og/eller vansker med å tilpasse sine følelsesmessige reaksjoner til det som situasjonen til enhver tid krever - overdrevent eller feilplassert utrykk for sinne, uro, angst, tristhet, ensomhet eller avhengighet. Senere i barnealderen domineres bildet av tegn på overdrevne, feilplasserte eller bisarre følelsesmessige reaksjoner. Vansker i forbindelse med rutinemessige aktiviteter tones gjerne ned som indikatorer på atferdsvansker.

På tvers av måleinstrumenter, utvalg og analysemetoder, er forskere flest enige om at de fleste typer av problematferd kan plasseres inn under to underkategorier; utagerende vansker ("externalising problems": aggresjon, konsentrasjonsvansker, problemer med selvregulering og ulydighet), og emosjonelle vansker ("internalising problems": depresjon, engstelse og tilbaketrekking) (Achenbach et al., 1991). Utagerende vansker og mer emosjonelle reaksjonsformer er vanligvis funnet å overlappe gjennom hele barndommen (Verhulst \& Van der Ende, 1992, 1993). Data fra et stort longitudinelt studie av et australsk utvalg viste at omlag en tredjedel av barna som hadde høye skårer på en av vanskedimensjonene gjennomgående også hadde forhøyede skårer på den andre (Prior et al., 2000). Selv om det er klare etiologiske fellestrekk mellom disse to hovedtypene av problematferd, antas imidlertid hver av problemtypene i tillegg å være påvirket av særegne forhold. Vi har imidlertid utilstrekkelig kunnskap om hvilke risikofaktorer som kun bidrar til opprettholdelsen av utagerende problematferd, hvilke som kun har innvirkning på emosjonelle typer av problemer, og hvilke som øker sannsynligheten for at begge typer av problematferd vedvarer (Prior et al., 1992).

\section{Forstadier til manifeste vansker - problematferd hos de yngste barna}

Barneforskere har vært overraskende lite opptatt av problematferd hos de aller yngste barna. Foreløpig vet vi blant annet ikke om ulike former for problematferd hos barn som er yngre enn to år overhodet lar seg dele inn i vansketyper. I så vidt lave aldre er det selvfølgelig mulig at barnas vansker med å tilpasse seg dag- lige rutiner og følelsesmessige krav uttrykkes gjennom skiftende og enkeltstående atferdsformer som det ikke er rimelig å knytte sammen til mer stabile mønstre. Og selv om det skulle vise seg at ulike typer av problematferd hos ett- til toår gamle barn er forbundet med hverandre på måter som gjør det mulig å utkrystallisere vanskedimensjoner med visse felles kjennetegn, er det ikke sikkert at problematferden lar seg dele inn $\mathrm{i}$ de samme dimensjonene på dette alderstrinnet som dem som ble funnet $\mathrm{i}$ utvalg av barn på to år eller mer.

Vi har ikke vært i stand til å finne en eneste befolkningsundersøkelse som har brukt en av de vanlige skalaene for måling av problematferd i førskolealderen til å studere vansker hos barn mellom ett og to år. Dette til tross for at slik kunnskap har både teoretisk interesse og praktisk betydning. Måleinstrumentene som anvendes i utvalg av eldre barn er heller ikke klinisk validerte til bruk i så vidt lave aldersgrupper. Skal de etablerte skalaene anvendes i utvalg av yngre barn, må det derfor sannsynliggjøres at spørsmålene skiller barn med problemer fra upåfallende barn også i denne aldersgruppen.

\section{Prediksjon av tilpasningsvansker}

Utvikling av tilpasningsvansker hos barn kan best forklares om en både tar hensyn til forhold ved oppvekstmiljøet og egenskaper ved barna selv. Depresjon hos mødrene er den eksterne risikofaktoren som klarest samvarierer med alle typer av tilpasningsvansker hos barn (Campbell, 1995). Det har vært anført at depresjon gjør mødrene mindre følelsesmessig tilgjengelige (Rutter, 1990) og at deres oppdragelsesmåter blir mer preget av kritikk enn det som er vanlig (Cummings \& Davies, 1994). En lang rekke andre omgivelsesfaktorer er i tillegg funnet å bidra til etablering og opprettholdelse av vansker hos barn som er tre-fire år og eldre. Fokus rettes vanligvis på vanskelige sosioøkonomiske forhold, negative livshendelser, lite sosial støtte fra venner og familie og konflikter mellom foreldrene (Richman et al., 1982; Holand \& Moos, 1987).

Individuelle særtrekk ved barna, som temperamentskjennetegn og somatiske skader og sykdommer, fører imidlertid til at barn reagerer ulikt på de samme eksterne påvirkningene (Oberklaid et al., 1997; Rothbart \& Bates, 1998). Dette innebærer at barna selv påvirker sitt omsorgsmiljø og derved også er med på å skape sin egen påvirkning.

\section{Behov for kunnskap i det forebyggende arbeid}

Effektiv forebygging av atferdsvansker fordrer god forståelse av faktorer og prosesser som er involvert $i$ etablering og opprettholdelse av problematferd. Selv om en rekke forskningsprosjekter har bidratt med slik viten, mangler vi fremdeles kunnskap på vesentlige områder. Særlig har vi sparsom kunnskap om hvorledes tilpasningsvansker uttrykkes hos ett- til toårs gamle barn, hvilke mønstre problematferden kan deles inn $i$, og hvor stabile vanskene er fra dette tidlige 
alderstrinn og fram til sen førskolealder (Campbell, 1995; Koot et al., 1997). Vi mangler derfor kunnskap som kan bidra i diskusjonen av hvilke atferdsformer som kan regnes som forstadier til tilpasningsvansker. Som følge av dette vet vi heller ikke hvilke forhold som øker sannsynligheten for at barn utvikler vansker allerede fra så vidt tidlig alder. Dette betyr at den delen av førstelinjetjenesten som arbeider med å forebygge psykiske lidelse hos barn: helsestasjonene, skolehelsetjenesten, PP-tjensten og barnevernet, mangler det kunnskapsgrunnlaget som gjør det mulig å rette forebyggende tiltak inn mot nettopp de barn og familier hvor tiltak må antas å ha sterkest effekt.

Flere studier (Koot et al., 1997; Prior et al., 1993) har vist at det allerede fra to-til treårsalderen er mulig å identifisere tilpasningsvansker hos barn. Om en skal forebygge at slike vansker oppstår, eller gripe inn enda tidligere i utviklingsforløpet, hadde det derfor vært ønskelig å kunne spore opp de ett- til toåringene som har forhøyet risiko for å utvikle tilpasningsvansker ett år senere. I Norge ligger forholdene godt til rette for arbeid med utsatte familier i de første par årene i barnas liv fordi barnefamilier flest har hyppig kontakt med personell ved helsestasjonene i løpet av denne perioden.

\section{Målsetting med dette studiet}

Den overordnede målsettingen med dette studiet er å undersøke hvorledes tilpasningsvansker hos barn arter seg $\mathrm{i}$ annet og tredje leveår og hvilke forhold som særlig synes å bidra til at vanskene utvikles og vedvarer.

Studiet søkte mer spesifikt å undersøke:

- Hvorvidt det er mulig å måle problematferd på en meningsfull måte allerede hos 18 måneder gamle barn, hvilke forekomster av vansker vi i så fall finner, og hvilke mønstre av vansker som synes å tre fram ved henholdsvis 18- og 30-måneders alderen.

- Hvor stabil problematferden synes å være fra 18 til 30 måneder.

- Hvilke kjennetegn ved omsorgsmiljøet og individuelle særtrekk ved barna som synes å virke inn på stabiliteten av alle typer av vansker, og hvilke risikoforhold som heller synes å være selektivt knyttet til bestemte vansketyper.

\section{Metode}

\section{Utvalget}

Det ble samlet inn opplysninger gjennom spørreskjemaer til ett årskull brukere av 19 helsestasjoner i syv kommuner eller kommunedeler i Øst-Norge. Svarprosenten var høy, fra 85 til 94 prosent fra en spørrerunde til den neste. Om lag 80 prosent av mødrene som besvarte det første spørreskjemaet svarte også på spørsmålene $\mathrm{i}$ det neste. Helsestasjonene har i tillegg gitt bakgrunnsinformasjon om familiene som ikke besvarte det første spørreskjemaet.
Foruten demografiske og sosioøkonomiske bakgrunnsforhold, ble det hver gang innhentet informasjon om mødrenes: symptomer på angst og depresjon (HSCL-25 - Hesbacher et al., 1980), somatiske helseproblemer, temperamentskjennetegn (EAS - Buss \& Plomin, 1984), mestringstil (Kidcope - Spirito et al., 1988), sosiale nettverk (kvantitet og sosial støtte fra henholdsvis partner, familie, venner og naboer Dalgard et al., 1995), langvarige belastninger og livshendelser siste år. Om barna ble det innhentet informasjon om: problematferd (BCL - Richman \& Graham, 1971), temperamentskjennetegn (EAS - Buss \& Plomin, 1984), tilknytningsatferd, og om symptomer på somatisk sykelighet og funksjonshemminger. I alle rundene ble det også samlet inn opplysninger fra mødrene om sosiale kvaliteter og spesielle problemer $i$ noermiljøet.

\section{Resultater}

\section{Problematferd hos de yngste forskolebarna}

BCL-skalaen ble anvendt til å måle problematferd hos barna da de var 18 måneder. Resultatene indikerer at det er mulig å identifisere problemer på en pålitelig måte allerede på dette alderstrinnet. Dette underbygges av at det ble funnet "Spearman's rangorden korrelasjoner" (her: et uttrykk for resultatet av en sammenligning av den relative hyppigheten av ulike former for problematferd mellom to utvalg) på henholdsvis $0,85 \mathrm{og}$ 0,86 mellom utvalget av halvannet år gamle norske barn og to utvalg av engelske treåringer: utvalget som ble brukt til den opprinnelige valideringen av BCLskalaen (Richman et al., 1982) og et annet, større, utvalg som ble undersøkt mer nylig (Stallard, 1993). Dette er nærmere utdypet i en artikkel fra 2000 (Mathiesen \& Sanson, 2000) Forekomsten av de ulike formene for problematferd endret seg imidlertid noe fra barna var 18 måneder til de ble $21 / 2$ år. Tabell 1 gir en oversikt over forekomsten av ulike typer av problematferd på disse to tidspunktene og eventuelle endringer i disse.

En faktorstruktur med fire vanskedimensjoner trådte fram på begge måletidspunktene: to dimensjoner kjennetegnet av utagerende problematferd, henholdsvis vansker med "sosial tilpasning" og med "overaktivitetpassivitet"; en dimensjon knyttet til emosjonell problematferd, vansker med "emosjonell tilpasning", og en fjerde vanskedimensjon knyttet til generell umodenhet, "selvreguleringsproblemer". Faktorstrukturen på de to måletidspunktene er vist i tabell 2.

Selv om dimensjonene syntes å ha moderate testretest korrelasjoner (verdier fra 0,32 til 0,51), var det god overensstemmelse mellom mønstret som trådte fram hos "våre" 18-måneder gamle barn og mønstre som ellers er funnet $\mathrm{i}$ studier av barn som er to år og eldre (Sonuga-Barke et al., 1997). Selv om vårt kartleggingsinstrument var noe enklere enn $\mathrm{CBCL} / 2-3$, identifiserte dette fire av de seks "kjerne-syndromene" 
Tabell 1. Prosentandelen barn med alvorlige problemer på de 19 BCL spørsmålene ${ }^{1}$ ved henholdsvis 18 og 30 måneder (andelen med moderate problemer er satt $\mathrm{i}$ parentes). Testing av hvorvidt forskjellen mellom skårene på $t_{1}$ and $t_{2}$ på de 11 atferdskategoriene som problematferden deles inn i er signifikant.

\begin{tabular}{|c|c|c|c|c|}
\hline \multirow[b]{2}{*}{ Kategorier og spørsmål } & \multirow[b]{2}{*}{$\begin{array}{c}18 \text { mnd. }\left(t_{1}\right) \text {, } \\
n=921\end{array}$} & \multirow[b]{2}{*}{$\begin{array}{c}30 \text { mnd. }\left(\mathrm{t}_{2}\right) \\
\mathrm{n}=784\end{array}$} & \multicolumn{2}{|c|}{$\begin{array}{l}\text { "McNemar's test of differences" mellom } \\
\text { skårene ved } t_{1} \text { og } t_{2}, n=750 \text {, Exact Sig. }\end{array}$} \\
\hline & & & $\begin{array}{l}\text { Både moderate og } \\
\text { alvorlige problemer }\end{array}$ & $\begin{array}{l}\text { Kun alvorlige } \\
\text { problemer }\end{array}$ \\
\hline Spiseproblemer & $4,1(47,3)$ & $8,3(61,6)$ & 0,000 & 0,005 \\
\hline Dårlig appetitt & $2,5(29,6)$ & $4,5(44,3)$ & & \\
\hline Kresen & $2,9(36,2)$ & $5,0(49,0)$ & & \\
\hline Søvnvansker & $8,8(57,4)$ & $11,6(55,5)$ & 0,272 & 0,009 \\
\hline Vansker med å sovne om kvelden & $2,2(20,7)$ & $3,2(19,9)$ & & \\
\hline Hyppig oppvåking & $4,1(55,4)$ & $1,9(56,1)$ & & \\
\hline Sover i foreldrenes seng & $5,6(23,5)$ & $8,7(31,1)$ & & \\
\hline For aktiv & $6,6(79,3)$ & $5,2(74,0)$ & 0,161 & 0,161 \\
\hline Dårlig konsentrasjon & $7,1(71,1)$ & $3,1(51,9)$ & 0,000 & 0,000 \\
\hline Klengete/krevende & $4,8(75,4)$ & $3,1(65,4)$ & 0,000 & 0,188 \\
\hline Avhengig & $1,1(24,1)$ & $0,4(19,6)$ & & \\
\hline Oppmerksomhetssøkende & $4,2(72,9)$ & $2,7(61,1)$ & & \\
\hline Vanskelig å oppdra & $3,3(52,7)$ & $2,7(56,8)$ & 0,021 & 0,597 \\
\hline Raserianfall & $1,5(55,0)$ & $0,9(67,0)$ & 0,000 & 0,791 \\
\hline Irritabel & $0,7(5,3)$ & $0,5(6,5)$ & 0,532 & 0,754 \\
\hline Bekymret & $0,7(18,8)$ & $0,9(26,4)$ & 0,000 & 0,727 \\
\hline Engstelig & $0,3(43,3)$ & $0,1(21,0)$ & 0,000 & $*$ \\
\hline Dårlig forhold til søsken og andre barn & $0,1(9,3)$ & $0,1(12,5)$ & $*$ & $*$ \\
\hline Dårlig forhold til søsken & $0,1(3,0)$ & $0,1(7,0)$ & & \\
\hline Dårlig forhold til jevnaldrende & $0,0(7,2)$ & $1,0(6,0)$ & & \\
\hline Urenslig $^{1}$ & & 89,5 & & \\
\hline Tisser på seg om natten ${ }^{1}$ & & 91,1 & & \\
\hline Tisser på seg om dagen ${ }^{1}$ & & 87,1 & & \\
\hline Bæsjer på seg ${ }^{1}$ & & 89,5 & & \\
\hline
\end{tabular}

${ }^{1}$ Spørsmålene om renslighet ble ekskludert fra spørreskjemaet ved 18 måneder, og skåret som dikotome variable ved 30 måneder, fordi mesteparten av barna fremdeles brukte bleier ved disse tidspunktene. En positiv skåre ved 30 måneder betyr her at barnet har "et uhell" en gang i uken eller mer, eller at barnet framdeles bruker bleier.

* McNemar's test kunne ikke beregnes fordi forekomsten var $<1 \%$.

Tabell 2. Faktorstrukturen som de 11 atferdskategoriene ${ }^{1}$ fra BCL dannet ved 30 måneder (faktorladningene ved 18 måneder er satt i parentes) sortert inn under fire vanskedimensjoner $(\mathrm{n}=750)$.

\begin{tabular}{|c|c|c|c|c|}
\hline & \multicolumn{4}{|c|}{ Varimax Rotert Faktor Matrise } \\
\hline & SOS & REG & EMO & OP \\
\hline \multicolumn{5}{|l|}{ Sosial tilpasning (SOS) } \\
\hline Raserianfall & $0,65(0,90)$ & $0,24(0,00)$ & $0,00(0,00)$ & $-0,26(0,00)$ \\
\hline Vanskelig å oppdra & $0,60(0,49)$ & $0,26(0,18)$ & $-0,11(0,00)$ & $0,26(0,42)$ \\
\hline Dårlig forhold til søsken og andre barn & $0,60(0,25)$ & $-0,14(0,58)$ & $0,27(0,15)$ & $0,00(0,00)$ \\
\hline Irritabel & $0,56(0,26)$ & $0,11(0,18)$ & $0,00(0,14)$ & $0,27(0,44)$ \\
\hline \multicolumn{5}{|l|}{ Selvregulering (REG) } \\
\hline Søvnvansker & $0,00(0,11)$ & $0,73(0,68)$ & $-0,11(0,00)$ & $0,00(0,00)$ \\
\hline Klengete/krevende & $0,15(0,13)$ & $0,58(0,27)$ & $0,19(0,22)$ & $0,25(0,55)$ \\
\hline Spiseproblemer & $0,11(0,17)$ & $0,40(0,68)$ & $0,12(0,00)$ & $0,00(0,00)$ \\
\hline \multicolumn{5}{|l|}{ Emosjonell tilpasning (EMO) } \\
\hline Bekymret & $0,00(0,00)$ & $0,28(0,16)$ & $0,81(0,74)$ & $0,00(0,00)$ \\
\hline Engstelig & $0,00(0,00)$ & $0,00(0,00)$ & $0,71(0,80)$ & $0,00(0,00)$ \\
\hline \multicolumn{5}{|l|}{ Overaktiv-passiv $(O P)$} \\
\hline Dårlig konsentrasjon & $0,00(0,00)$ & $0,21(0,00)$ & $0,00(0,00)$ & $0,80(0,69)$ \\
\hline For aktiv & $0,37(0,00)$ & $-0,11(0,00)$ & $0,00(0,00)$ & $0,60(0,68)$ \\
\hline
\end{tabular}

${ }^{1}$ Spørsmålene om renslighet er ekskludert. 
som Koot et al. (1997) og Achenbach (1992) fant med CBCL/2-3 gjennom studier av henholdsvis nederlandske og amerikanske barnepopulasjoner.

\section{Stabilitet $i$ vansker}

Problematferden som ble identifisert hos de norske barna ved 18 måneders alderen syntes også å ha en rimelig grad av stabilitet. Test-retest korrelasjon mellom vanskeskårene ved 18 og 30 måneder var på 0,58. Dette indikerte at omlag en tredjedel av variasjonen i problematferd hos to- til treåringene kunne forklares ved hjelp av tilsvarende problematferd ett år tidligere. Som forventet, syntes prediksjonskraften å være sterkest på de to endepunktene av skalaen: En tre-ganger-tre ruters krysstabell viste at 56 prosent av de omlag 15 prosentene av barna med mest omfattende problemer ved 30-månedersalderen også hadde vært plassert $\mathrm{i}$ den tilsvarende vanskegruppen ved 18 måneder, 20 prosent av barna med noen problemer (ett standardavvik over utvalgsgjennomsnittet) var klassifisert på lignende måte på begge tidspunkter, mens 89 prosent av barna uten problemer ved 30 måneder heller ikke hadde hatt slike ett år tidligere. Tabell 3 viser stabiliteten $i$ vansker når problematferden er delt inn $i$ de fire undergruppene.

\section{Globale tilpasningsvansker og omgivelsesforhold}

I vår studie fant vi at symptomnivået til mødre med 18 måneder gamle barn først og fremst hang sammen med daglige belastninger (problemer med egen helse, ekte- felles helse, barnets helse, bolig, arbeid og barnepassordninger) og med forholdet til andre (sosial støtte fra ektefelle, venner og familie). Det ble også funnet sammenhenger mellom mødrenes symptomnivå og bakgrunnsforhold som lav alder, lavt utdanningsnivå og ingen deltakelse $\mathrm{i}$ arbeidslivet utenfor hjemmet (Mathiesen et al., 1999).

Når det gjaldt barna, fant vi at problematferden til de 18 måneder gamle barna var sterkest knyttet til symptomer på angst og depresjon hos mødrene (Mathiesen, 1999). I tillegg synes noen av omgivelsesfaktorene som påvirket mødrene også å ha uavhengige virkninger på barna. Lav alder og utdanning hos mødrene, og lite sosial støtte, syntes både å være direkte forbundet med mødrenes symptomnivå og å ha uavhengige effekter på tilpasningsvansker hos barna. Andre faktorer i omsorgsmiljøet syntes bare å ha indirekte virkninger på barnas problematferd. Virkningen av belastningsforhold synes for eksempel kun å påvirke barna $\mathrm{i}$ den grad slike forhold virket inn på mødrenes symptomnivå.

Tabell 3. Antallet, og prosentandelen, barn inkludert i problemgruppen på hver faktor på de to måletidspunktene, samt andelen barn som både hadde problemer på $\mathrm{t}_{1}$ og $\mathrm{t}_{2}$.

\begin{tabular}{llll}
\hline & \multicolumn{1}{c}{$\mathrm{t}_{1}$} & \multicolumn{1}{c}{$\mathrm{t}_{2}$} & \multicolumn{1}{c}{$\mathrm{t}_{1} \mathrm{og} \mathrm{t}_{2}$} \\
\hline Sosial tilpasning & $67(8,9 \%)$ & $34(4,5 \%)$ & $19(2,5 \%)$ \\
Emosjonell tilpasning & $107(14,3 \%)$ & $88(11,7 \%)$ & $29(3,9 \%)$ \\
Overaktiv-passiv & $46(6,1 \%)$ & $52(6,9 \%)$ & $19(2,5 \%)$ \\
Selvregulering & $75(10,0 \%)$ & $98(13,1 \%)$ & $21(2,8 \%)$ \\
\hline
\end{tabular}

Tabell 4. Forekomst av somatiske helseproblemer hos barna, mentale helseproblemer hos mødrene og negative livshendelser og kroniske belastninger i familiene $(\mathrm{n}=750)$.

\begin{tabular}{|c|c|c|}
\hline & \multicolumn{2}{|c|}{$\begin{array}{l}\text { Prosentandel mødre som } \\
\text { rapporterte problemer }\end{array}$} \\
\hline & 18 mnd. & 30 mnd. \\
\hline \multicolumn{3}{|l|}{ Barns somatiske helse } \\
\hline Funksjonshemminger & 4,0 & 3,0 \\
\hline Infeksjonssykdommer, fem eller flere episoder & 21,7 & 17,3 \\
\hline Fordøyelsesvansker, to eller flere episoder & 20,9 & 19,5 \\
\hline Allergi & 11,4 & 12,9 \\
\hline Andre sykdommer, fem eller flere episoder & 9,7 & 6,4 \\
\hline \multicolumn{3}{|l|}{ Modrenes mentale helse } \\
\hline Symptomer på angst og depresjon & 20,7 & 17,3 \\
\hline \multicolumn{3}{|l|}{ Negative livshendelser og kroniske belastninger } \\
\hline Negative livshendelser, to eller flere & 16,8 & 19,3 \\
\hline Boligproblemer (vedlikehold, leieforhold og lignende,) & 20,1 & 16,9 \\
\hline Problemer med arbeid (arbeidsløshet, usikkert arbeid, vanskelige arbeidsforhold) & 33,3 & 26,9 \\
\hline Helseproblemer hos ektefelle (somatiske eller mentale) & 8,7 & 8,4 \\
\hline Problemer med barnepass (barnehage, dagmamma, syke barn) & 28,8 & 29,1 \\
\hline Økonomiske problemer (betaling av husleie, lån, forpliktelser og lignende) & 36,4 & 31,6 \\
\hline Samlivsproblemer (mye krangel, alvorlige samlivsproblemer, separasjon, skilsmisse) & 23,9 & 24,7 \\
\hline
\end{tabular}




\section{Ulike former for tilpasningsvansker, barnas tempera-} ment og forhold i omgivelsene

Tabell 4 gir en oversikt over forekomsten av somatiske helseproblemer hos barna, mentale helseproblemer hos mødrene og negative livshendelser og kroniske belastninger i familiene.

For å finne fram til predikorer for vedvarende vansker på hver av de fire områdene tilpasningsvansker ble delt inn i, ble skårene på de fire temperamentindeksene i EAS-skalaen (grad av emosjonalitet, skyhet, sosialitet og aktivitet) inkludert $i$ analysene av prediktorer sammen med opplysninger om barnas somatiske helse, demografiske variable, mødrenes symptomnivå og støtte- og belastningsforhold i familien. Resultatene viste at sjansene for at alle de fire hovedformene for tilpasningsvansker (vansker med henholdsvis: "sosial tilpasning", "emosjonell tilpasning", "overaktiv-passiv" og "selvregulering") vedvarte fra 18- til 30-måneder var større om mødrene hadde et høyt symptomnivå på det første måletidspunktet og om barnas temperament var preget av emosjonalitet ved denne alderen. Det er verd å merke seg at det ikke ble funnet slike generelle effekter fra noen av de andre prediktorene.

Selv om høyt symptomnivå hos mødrene og høyt nivå av temperamentsmessig emosjonalitet hos barna økte risikoen for at alle typer av vansker skulle vare ved, syntes andre forhold ved mødrene, i omgivelsene, eller ved barna selv, kun å være knyttet til enkelte av vanskedimensjonene. På denne måten tyder resultatene på at stabiliteten $i$ vansker henger sammen med forskjellige mønstre av risikofaktorer for alle de fire vansketypene (Mathiesen \& Sanson, 2000).

Resultatene viste at barna med vedvarende vansker, uavhengig av type, hadde de mest problematiske familieforholdene og de vanskeligste individuelle kjennetegnene, sammenlignet med barna uten problemer. Barna med vansker på kun ett av tidspunktene, enten ved 18 eller ved 30 måneder, syntes å ha middelverdier på prediktorvariablene.

\section{DISKUSJON}

\section{Måling av tilpasningsvansker i tidlig forskolealder}

Mye av vår kunnskap om utvikling av atferdsvansker hos barn er hentet fra store befolkningsundersøkelser. De større longitudinelle prosjektene har imidlertid vanligvis først målt vansker hos barn fra treårsalderen og framover. Dette kan henge sammen med en antagelse om at stabiliteten i problematferd er for lav før denne alderen. Som en konsekvens av dette rapporterte blant annet Richman og kolleger (1982) at de nølte med å begynne målinger av vansker i tidligere aldersgrupper på grunn av faren for en sammenblanding mellom ustabil problematferd som skyldes biologisk umodenhet, og mer langvarig problematferd som antas å være forårsaket av indre konflikter. En beslektet type reservasjon mot tidlige målinger av vansker er kommet fra temperamentsforskere som Buss og Plomin (1984). Disse anførte at barns problematferd synes å være så vidt udifferensiert $i$ de tidligste aldersgrupper at det er vanskelig å skille godt nok mellom ulike typer av emosjonelle reaksjoner.

Det er foreløpig kun CBCL som er klinisk validert til å måle vansker hos barn mellom to og tre år. Forskning fra USA (Achenbach, 1992; Achenbach et al., 1987) og Nederland (Koot et al., 1997) indikerer god reliabilitet og diskriminerende validitet for $\mathrm{CBCL} / 2-3$, en alderstilpasset versjon av CBCL-skalaen for barn mellom fire og 16 år. Resultater fra det omfattende valideringstudiet til Koot et al. (1997) støttet imidlertid ingen av de to typene av anfektelser mot målinger av vansker hos barn under tre år. De nederlandske forskerne fant lave korrelasjoner mellom tilpasningsvansker og biologisk utviklingsstatus i sitt utvalg av 420 to- til treåringer (mellom skårene på CBCL/2-3 og skårene på Minnesota Child Development Inventory, Ireton \& Thwing, 1974). En eventuell sammenblanding mellom tilpasningsvansker og biologisk umodenhet synes derved ikke å skape problemer for målingene av vansker $\mathrm{i}$ dette utvalget. Siden symptomene på tilpasningsvansker også lot seg dele inn i seks undergrupper med tilfredsstillende indre validitet og test-retest reliabilitet, støttet undersøkelsen heller ikke antagelsen om at vansker hos barn under tre år i hovedsak uttrykkes gjennom mer udifferensierte kategorier.

Det er imidlertid en tredje type av usikkerhet ved tidlige målinger av tilpasningsvansker som vi også er nødt til å merke oss. Sentrale relasjonsforskere som Sameroff og Emde (1989) argumenterer for at tilpasningsvansker i tidlig førskolealder heller må sees på som forstyrrelser i mor-barn samspillet enn som uttrykk for problematiske reaksjonstilbøyeligheter rotfestet $\mathrm{i}$ barnet. Innen denne tradisjonen antas stabiliteten i vansker som er funnet fra tidlig førskolealder og framover primært å være forårsaket av stabilitet $\mathrm{i}$ mor-barn forholdet.

Dette problemkomplekset er også tatt opp av Rothbart og Bates (1998) i en omfattende gjennomgang av forskning omkring tidlig utvikling. De konkluderer med at tilpasningsvansker hos de yngste førskolebarna antakeligvis både er uttrykk for problemer i mor-barn forholdet, følelsesmessige problemer rotfestet i barnet, og målefeil, og at dagens kunnskap ikke gir oss muligheter til å skille disse problemkategoriene fra hverandre. I tråd med dette siste fokuserer vår studie på problematferd som mødrene til de yngste førskolebarna (ett- til treåringene) mener vanskeliggjør barnas tilpasning til rutinemessige gjøremål og vanlige situasjoner, uavhengig av om slik atferd primært er et uttrykk for samspillsproblemer eller for problemer "inne" i barnet.

På bakgrunn av våre resultater synes det å være rimelig å slutte at problematferd hos 18 måneder gamle barn kan, i noen grad, sees på som forstadier til tilpasningsvansker. I tillegg er det teoretiske grunner til å anta at problematferd i denne lave alderen også er ut- 
trykk for forbigående biologisk umodenhet (Richman et al., 1982) og situasjonsbestemte samspillsvansker (Sameroff \& Emde, 1989).

Vi finner også støtte for å hevde at de fleste former for problematferd syntes å danne meningsfulle mønstre med distinkte kjennetegn allerede ved 18-månedersalderen. Disse vansketypene lignet på dem som tidligere er identifisert gjennom studier av eldre førskolebarn. Selv om mønstrene syntes å bli klarere fra 18 til 30 måneder, indikerte resultatene at barna hadde begynt å utvikle sine spesielle måter å uttrykke vansker på allerede i annet leveår.

\section{Prediktorer for vedvarende tilpasningsvansker}

Vi fant at det var lineære sammenhenger mellom stabiliteten i vansker og prediktorene. Barn med stabile vansker hadde de høyeste skårene på alle prediktorer som ga et signifikant bidrag til forklaringen av vansker. Barn som hadde vansker på et av måletidspunktene, men ikke på begge, hadde middelverdier på prediktorvariablene. Dette ble også funnet i en stor longitudinell studie fra Australia (Prior et al., 1992). Den australske studien undersøkte imidlertid stabiliteten i globale vansker fra treårsalderen og fram til åtte år, og de brukte langt færre prediktorer. Vi har ikke vært i stand til å finne andre studier som har forsøkt å predikere stabiliteten i vansker av ulike typer, og heller ikke studier som har brukt både 18-måneders kjennetegn ved barna og deres omsorgsmiljø i prediksjonene.
Oppsummeringsvis vil vi anføre at det er temmelig vanlig at 18 måneder gamle barn viser tegn på tilpasningsvansker. Resultatene tyder likevel på at vi allerede fra dette tidspunktet kan begynne å identifisere kjennetegn både ved barna og ved omsorgsmiljøet som kan bidra til å predikere hvilke barn som vil ha vedvarende problemer og hvilke som heller vil ha mer forbigående vansker. Vi har ikke funnet andre befolkningsundersøkelser som presenterer resultater fra studier av "vanlige" former for tilpasningsvansker hos barn i det andre leveåret. Dette betyr at en rekke av våre funn ikke kan vurderes $i$ lys av resultater fra andre utvalg av halvannetåringer. Det unike ved resultatene er utfordrende. Samtidig bidrar dette til at diskusjoner om dataenes pålitelighet må ha en sentral plass ved tolkninger av funnene.

Det er viktig å merke seg at vi foreløpig kun har undersøkt stabiliteten i en kort tidsperiode i barnas liv, fra halvannet til to og et halvt år. I tillegg til at vi ikke kan sammenligne våre resultater med resultater fra andre tilsvarende undersøkelser, vet vi foreløpig ikke hvordan barna vil utvikle seg videre. Det kan for eksempel være at en stor andel av barna med vansker i 18-månedersalderen, men ikke ved 30 måneder, vil utvikle vansker på et senere tidspunkt. Likeledes vet vi ikke om barna som kun hadde vansker ved 30-måneder fortsatt vil ha vansker ett år senere. Denne typen usikkerhet gjør at vi foreløpig bare kan peke på tendenser og ikke trekke sikre konklusjoner fra analysene.

\section{REFERANSER}

Achenbach TM (1992). Manual for the Child Behavior Checklist/2-3 and 1992 profile. Burlington: University of Vermont, Department of Psychiatry.

Achenbach TM, Edelbrock C, Howel CT (1987). Empirically based assessment of the behavioral/emotional problems of 2- and 3-year old children. J Abnorm Child Psychol, 15, 629-650.

Achenbach TM, Howel CT, Quay HC, Conners CK (1991). National survey of problems and competencies among four-to sixteen-year-olds. Monographs of the Society for Research in Child Development, Serial No. 225, Vol. 56 (3).

Buss AH, Plomin R (1984). Temperament: Early developing personality traits. Hilsdale, NJ: Lawrence Erlbaum.

Campbell SB (1995). Behavior problems in preschool children: a review of recent research. J Child Psychol Psychiatry, 36 (1), 113-149.

Cummings E, Davies T (1994). Maternal depression and child development. J Child Psychol Psychiatry, 35 (1), 73-112.

Dalgard OS, Bjørk S, Tambs K (1995). Social support, negative life events and mental health - a longitudinal study. Br J Psychiatry, 166, 29-43.

Hesbacher PT, Rickels R, Morris RJ, Newman H, Rosenfeld MD (1980). Psychiatric illness in family practice. $J$ Clin Psychiatry, 41, 6-10.

Holand CJ, Moos RH (1987). Risk, resistance, and psychological distress: A longitudinal analysis with adults and children. J Abnorm Psychol, 96 (1), 3-13.

Ireton H, Thwing EJ (1974). Minnesota Child Development Inventory. Minneapolis: Behavior Science Systems.

Koot HM, Verhulst FC (1991). Prevalence of problem behavior in Dutch children aged 2-3. Acta Psychiatr Scand, Supplement No. 367 (83).

Koot HM, Van den Oord EJCG, Verlhulst FC, Boomsma DI (1997). Behavioral and emotional problems in young preschoolers: Cross-cultural testing of the validity of the Child Behavior checklist 2/3. J Abnorm Child Psychol, 25 (3), 183-196. 
Mathiesen KS (1999). Prediktorer for tilpasningsvansker hos førskolebarn. Doktorgradsavhandling. Psykologisk institutt, Universitetet i Oslo.

Mathiesen KS, Tambs K, Dalgard OS (1999). The influence of social class, strain, and social support on symptoms of anxiety and depression in mothers of toddlers. Soc Psychiatry Psychiatr Epidemiol, 34, 61-72.

Mathisen KS, Sanson A (2000). Dimensions of early childhood behaviour problems - Stability and predictors of change from 18 to 30 months. J Abnorm Child Psychol, 28 (1), 15-31.

Oberklaid F, Amos D, Liu C, Jarman F, Sanson A, Prior M (1997). “Growing pains": Clinical and behavioral correlates in a community sample. J Dev Behav Pediatr, 18, 102-106.

Prior M (1992). Childhood temperament. J Child Psychol Psychiatry, 33 (1), 249-279.

Prior M, Sanson A, Smart D, Oberklaid F (2000). Pathways from infancy to adolescence: Australian temperament project 1983-2000. Australian Institute of Family Studies.

Prior M, Smart D, Sanson A, Oberklaid F (1993). Sex differences in development from infancy to eight years: Results from a community survey. J Am Acad Child Adolesc Psychiatry, 32, 291-305.

Prior M, Smart D, Sanson A, Pedlow R, Oberklaid F (1992). Transient versus stable behaviour problems in a normative sample: Infancy to school age. J Pediatr Psychol, 17 (4), 423-443.

Richman N, Graham PJ (1971). A behavioural screening questionnaire for use with three-year-old children: preliminary findings. $J$ Child Psychol Psychiatry, 12, 5-33.

Richman N, Stevenson J, Graham PJ (1982). Pre-school to school: A behavioural study. London: Academic Press.

Rothbart MK, Bates JE (1998). Temperament. In: Damon W, ed. Handbook of child psychology, Vol. 3. Social, emotional and personality development ( $5^{\text {th }}$ edn.). New York: Wiley, 105-176.

Rutter M (1990). Commentary: Some focus and process considerations regarding effects of parental depression on children. Dev Psychol, 26 (1), 60-67.

Sameroff AJ, Emde RN (1989). Relationship disturbances in early childhood: A developmental approach. Basic Books, USA.

Sonuga-Barke EJS, Thompson M, Stevenson J, Viney D (1997). Patterns of behaviour problems among preschool children. Psychol Med, 27, 909-918.

Spirito A, Stark LJ, Williams C (1988). Development of a brief coping checklist for use with pediatric populations. J Pediatr Psychol, 13 (4), 555-574.

Stallard P (1993). The behaviour of 3-year-old children: Prevalence and parental perception of problem behaviour: a research note. J Child Psychol Psychiatry, 34, 413-421.

Verhulst FC, Van der Ende J (1992). Six-year stability of parent-reported problem behavior in an epidemiological sample. J Abnorm Child Psychol, 20 (6), 595-610.

Verhulst FC, Van der Ende J (1993). "Comorbidity" in an epidemiological sample: a longitudinal perspective. $J$ Child Psychol Psychiatry, 34 (5), 767-783.

Verhulst FC, Van der Ende J (1995). The eight-year stability of problem behavior in an epidemiological sample. Pediatr Res, 38 (4), 612-617. 